\title{
Galactinol Is a Signaling Component of the Induced Systemic Resistance Caused by Pseudomonas chlororaphis 06 Root Colonization
}

\author{
Mi Seong Kim,, ${ }^{1}$ Song Mi Cho, ${ }^{2}$ Eun Young Kang, ${ }^{1}$ Yang Ju Im, ${ }^{1}$ Hoon Hwangbo, ${ }^{1}$ Young Cheol Kim, ${ }^{1}$ \\ Choong-Min Ryu, ${ }^{3}$ Kwang Yeol Yang, ${ }^{1}$ Gap Chae Chung, ${ }^{1}$ and Baik Ho Cho ${ }^{1}$ \\ ${ }^{1}$ Agricultural Plant Stress Research Center, Biotechnology Research Institute, College of Agriculture and Life Sciences, \\ Chonnam National University, Gwangju 500-757, Republic of Korea; ${ }^{2}$ Department of Floriculture, Chunnam Techno College, \\ Jeonnam 516-991, Republic of Korea; ${ }^{3}$ Systems Microbiology Research Center, KRIBB, Daejon 305-333, Republic of Korea
}

Submitted 14 February 2008. Accepted 25 July 2008.

\begin{abstract}
Root colonization by Pseudomonas chlororaphis 06 in cucumber elicited an induced systemic resistance (ISR) against Corynespora cassiicola. In order to gain insight into O6-mediated ISR, a suppressive subtractive hybridization technique was applied and resulted in the isolation of a cucumber galactinol synthase $(C s G o l S 1)$ gene. The transcriptional level of $\mathrm{CsGolS1}$ and the resultant galactinol content showed an increase several hours earlier under $\mathrm{O6}$ treatment than in the water control plants following $C$. cassiicola challenge, whereas no difference was detected in the plants without a pathogen challenge. The CsGolS1-overexpressing transgenic tobacco plants demonstrated constitutive resistance against the pathogens Botrytis cinerea and Erwinia carotovora, and they also showed an increased accumulation in galactinol content. Pharmaceutical application of galactinol enhanced the resistance against pathogen infection and stimulated the accumulation of defenserelated gene transcripts such as PRIa, PRIb, and NtACSI in wild-type tobacco plants. Both the CsGolS1-overexpressing transgenic plants and the galactinol-treated wild-type tobacco plants also demonstrated an increased tolerance to drought and high salinity stresses.
\end{abstract}

Plants have evolved a variety of mechanisms by which to defend themselves against pathogens. In addition to their constitutive barriers, plants can induce resistance against pathogenic attack upon appropriate stimulation prior to contact with the pathogens. Thus far, two types of induced resistance have been defined on the basis of differences in their stimulation: systemic acquired resistance (SAR) and induced systemic resistance (ISR) (Ryals et al. 1996; Van Loon et al. 1998). SAR is characterized by an early increase in endogenously synthesized salicylic acid (SA), coupled with the concomitant activation of a set of SAR genes (Ryals et al. 1996; Sticher et al. 1997). ISR, elicited by rhizobacteria, is capable of reducing disease in aboveground plant parts, and this has been demonstrated in a variety of plant species (Kloepper et al. 2004; Van Loon et al. 1998). The rhizobacterium Pseudomonas chloro-

Corresponding author: Baik Ho Cho; Telephone: +82 62530 2075; Fax: +82 62530 2079; E-mail: chobh@ chonnam.ac.kr

M. S. Kim and S. M. Cho contributed equally to this work.

*The $\boldsymbol{e}$-Xtra logo stands for "electronic extra" and indicates a supplemental figure is published online. raphis $\mathrm{O6}$ elicited ISR in tobacco and cucumber plants, demonstrating protective effects against two foliar bacterial pathogens, $P$. syringae pv. tabaci and Erwinia carotovora subsp. carotovora (Radtke et al. 1994; Spencer et al. 2003), and providing protection against the leaf spot fungus Corynespora cassiicola (Kim et al. 2004), respectively.

The signal transduction pathway of rhizobacteria-mediated ISR is known to be distinct from that of SAR. A rhizobacterium, $P$. fluorescens WCS417r, has been demonstrated to induce ISR via an SA-independent signaling pathway (Pieterse et al. 1996, 2002; Ton et al. 2002; Van Wees et al. 1997). Furthermore, components of the jasmonic acid (JA) and ethylene (ET) responses were required for the triggering of WCS417rmediated ISR (Knoester et al. 1999; Pieterse et al. 1998). Several other rhizobacterial strains, including $P$. fluorescens CHA0 (Iavicoli et al. 2003), P. fluorescens 89B61 (Yan et al. 2002), P. putida WCS358r (Van Wees et al. 1997), Serratia marcescens 90-166 (Press et al. 1997; Ryu et al. 2003), and Bacillus pumilus SE34 (Ryu et al. 2004; Yan et al. 2002) have been shown to induce SA-independent but ET- or JA-dependent signaling pathways for protection against plant pathogens. The exposure of the tobacco seedlings to $P$. chlororaphis O6 has been shown to stimulate the accumulation of transcripts for plant defense genes, including $P R-1 g$, 3-hydroxy-3-methyglutaryl coenzyme A reductase $(H M G R)$, and lipoxygenase $(L O X)$, but did not stimulate the accumulation of transcripts of the PR-1a gene (Spencer et al. 2003). This result suggests that strain O6 can activate the JA or ET plant defense pathways

Verhagen and associates (2004) investigated the transcriptional response of over 8,000 Arabidopsis genes during rhizobacteria-mediated ISR in an effort to identify ISR-related genes; however, none of the tested genes evidenced a consistent change in leaf expression in response to the effective colonization of the roots by WCS417r. After a challenge inoculation with the bacterial speck pathogen $P$. syringae pv. tomato on the WCS417r-induced plants, 81 genes evidenced augmented expression patterns within the leaves (Verhagen et al. 2004). This result indicates that these genes were primed to respond faster or more strongly when exposed to pathogenic attack. The capacity for augmented defense expression is referred to as "priming" and this phenomenon has been demonstrated in different plant species against different pathogens, insects, and even abiotic stresses (Conrath et al. 2002). P. chlororaphis O6mediated ISR was also associated with the fast induction of several genes after a challenge inoculation with $C$. cassiicola in cucumber leaves relative to water-treated controls (Kim et 
al. 2004). However, the physiological and molecular mechanisms underlying this priming phenomenon remain to be thoroughly elucidated. This lack of data compelled us to determine the genes involved in the priming phenomenon in plants.

The raffinose family oligosaccharides (RFO), including raffinose and stachyose, are common in the plant kingdom. RFO are not accumulated in vegetative tissues other than seeds, and their synthesis is induced in vegetative tissues during dehydration stress (Blackman et al. 1992; Brenac et al. 1997; Downie et al. 2003; Horbowicz and Obendorf 1994; Taji et al. 2002). Functions of RFO, other than their involvement in the desiccation tolerance of seeds, have been suggested to include transporting carbohydrates within the phloem (Ayre et al. 2003), the protection of plant cells against heat stress (Penikulangara et al. 2004), and protection from freezing (Pennycooke et al. 2003; Sprenger and Keller 2000). However, the specific function or functions of RFO in portions of plants other than the seeds remain largely unknown. The biosynthesis of RFO is preceded by the reversible addition of galactose units from galactinol to sucrose, and chain elongation is catalyzed via the consecutive action of raffinose synthase and stachyose synthase (Bachmann et al. 1994). The galactose donor, galactinol, is produced from UDP-Gal and myo-inositol via galactinol synthase (GolS) during the initial step in the biosynthesis of RFO. Galactinol has not been demonstrated to have any other function in plants other than as a galactosyl donor for RFO synthesis (Sprenger and Keller 2000). Three stress-responsive GolS genes (AtGolS1, 2, and 3) were recently identified in Arabidopsis. AtGolS1 and AtGolS2 were shown to be induced by drought and high-salinity stresses but not by cold stress. In contrast, AtGolS3 was induced by cold stress but not by drought or salt stress (Taji et al. 2002). Transgenic plants that overexpressed AtGolS2 cDNA demonstrated an enhanced level of galactinol and raffinose within leaves and evidenced improved drought tolerance (Taji et al. 2002). AtGolS1 gene expression was both drought stress inducible and heat inducible, and it was shown that the raffinose content within leaves increased upon heat stress in the wild-type strains but not in the AtGolS1 mutants (Penikulangara et al. 2004).

In this study, we have demonstrated that $P$. chlororaphis O6mediated ISR is associated with the primed expression of a galactinol synthase gene in plants. The gene was primed to respond faster and more strongly when exposed to pathogenic attack. The endogenous increase in galactinol contents within the plant leaves induced by O6 colonization or exogenously by pharmaceutical application conferred disease resistance against pathogen attack. To the best of our knowledge, this study is the first report to demonstrate that a simple disaccharide, galactinol, can function as a signaling factor for ISR against plant pathogens.

\section{RESULTS}

\section{Expression of a galactinol synthase (CsGolS1) gene is primed in the leaves of cucumber plants by $P$. chlororaphis 06 root colonization.}

Root colonization by $P$. chlororaphis $\mathrm{O} 6$ in cucumber elicited ISR against the fungal leaf spot disease caused by $C$. cassiicola (Kim et al. 2004) and the bacterial angular leaf spot disease caused by $P$. syringae pv. lachrymans, respectively (data not shown). An effort to detect specific genes involved in the $P$. chlororaphis O6-mediated ISR resulted in the isolation of several genes that demonstrated no consistent changes in expression levels in response to effective root colonization by the O6 strain. However, following a challenge inoculation with C. cassiicola onto the ISR-expressing cucumber leaves, these genes evidenced augmented expression patterns, indicating a much faster response time after pathogenic attack. For example, the transcript of the Cucumis sativus ISR gene 3 (CsISR3) clone, encoding a cucumber galactinol synthase (CsGolS1), was accumulated after a challenge inoculation with Corynespora cassiicola. The increased accumulation of the gene transcript occurred several hours earlier in the O6-colonized, challengeinoculated (O6+) leaves compared with only the challengeinoculated (O6-) leaves (Fig. 1A). The CsGolS1 gene transcript accumulated in $\mathrm{O} 6+$ plants as early as 0 to $12 \mathrm{~h}$ after inoculation, whereas this has been shown to occur after 12 to $24 \mathrm{~h}$ in O6- plants (Fig. 1A). These expression levels were also verified by real-time reverse-transcription polymerase chain reaction (RT-PCR) analysis (data not shown). On the cucumber leaves that were challenge inoculated with the bacterial pathogen $P$. syringae pv. lachrymans, the accumulation of the CsGolS1 gene transcript also increased far more rapidly in time and achieved a higher level in the O6+ plants than in the O6- plants (Fig. 1A). The initiation of CsGolS1 gene transcription was increased from $12 \mathrm{~h}$ after bacterial challenge in the O6+ leaves, whereas no increases was detected in the O6leaves until $24 \mathrm{~h}$ after the challenge inoculation.

In order to determine whether enhanced levels of CsGolSI gene expression are coupled to the increased de novo production of galactinol within cucumber leaves, we assessed the accumulation of endogenous galactinol levels by high-performance liquid chromatography (HPLC) in cucumber leaves in O6- and O6+ plants. Three different time points $(0,12$, and $24 \mathrm{~h}$ ) following the challenge inoculation with $C$. cassiicola were recorded. No differences were detected between treated and untreated plants in terms of the galactinol content on cucumber leaves prior to challenge with $C$. cassiicola. However, $12 \mathrm{~h}$ after challenge inoculation, the galactinol content in the O6+ cucumber leaves was found to be approximately 3.3fold higher than that detected in O6- leaves (Fig. 1B). Interestingly, the increased levels of galactinol content due to O6-mediated ISR faded within $12 \mathrm{~h}$ and, by $24 \mathrm{~h}$ following the challenge inoculation, the galactinol content had essentially declined to basal levels (Fig. 1B). The enhanced transcriptional level of the CsGolS1 gene in the O6+ cucumber leaves at $12 \mathrm{~h}$ persisted until $36 \mathrm{~h}$ after pathogen challenge (Fig. 1A); therefore, further investigations should be conducted regarding the sudden decrease in galactinol content observed at $24 \mathrm{~h}$. On the other hand, expression of the CsGols1 gene at $24 \mathrm{~h}$ in the O6cucumber challenged with the fungal pathogen does not coincide with elevated galactinol levels (Fig. 1B). Even when we divided the time points more narrowly $(0,8,16$, and $24 \mathrm{~h}$ after inoculation), elevated galactinol level was not detected in either the O6- or O6+ and challenged cucumber (data not shown). These facts suggest that an increased level of galactinol by the fungal infection may be used up very quickly to be a substrate for the synthesis of RFO and, possibly, to be a signal molecule for the defense signaling pathways (for example; inositol 1,4,5-triphosphate cycle and so on). If this is true, it is probable that the increased galactinol level can be detected only for a short period of time during the initial stage of ISR. Quantitative determination demonstrates that the amount of the CsGolS1 transcript at $24 \mathrm{~h}$ in O6- plants is far more than that at $12 \mathrm{~h}$ in $\mathrm{O} 6+$ plants (data not shown); therefore, increased galactinol level in O6- plants may be detectable for a certain period of time between 16 and $24 \mathrm{~h}$.

\section{Overexpression of the $\mathrm{Cs}$ GolS1 gene confers constitutive resistance in transgenic tobacco plants against fungal and bacterial pathogens.}

To support the functional role of galactinol in ISR, we generated transgenic tobacco plants in which the sense CsGolS1 transcript was constitutively overexpressed. We selected four 
A

Hours after challenge inoculation with Corynespora cassiicola

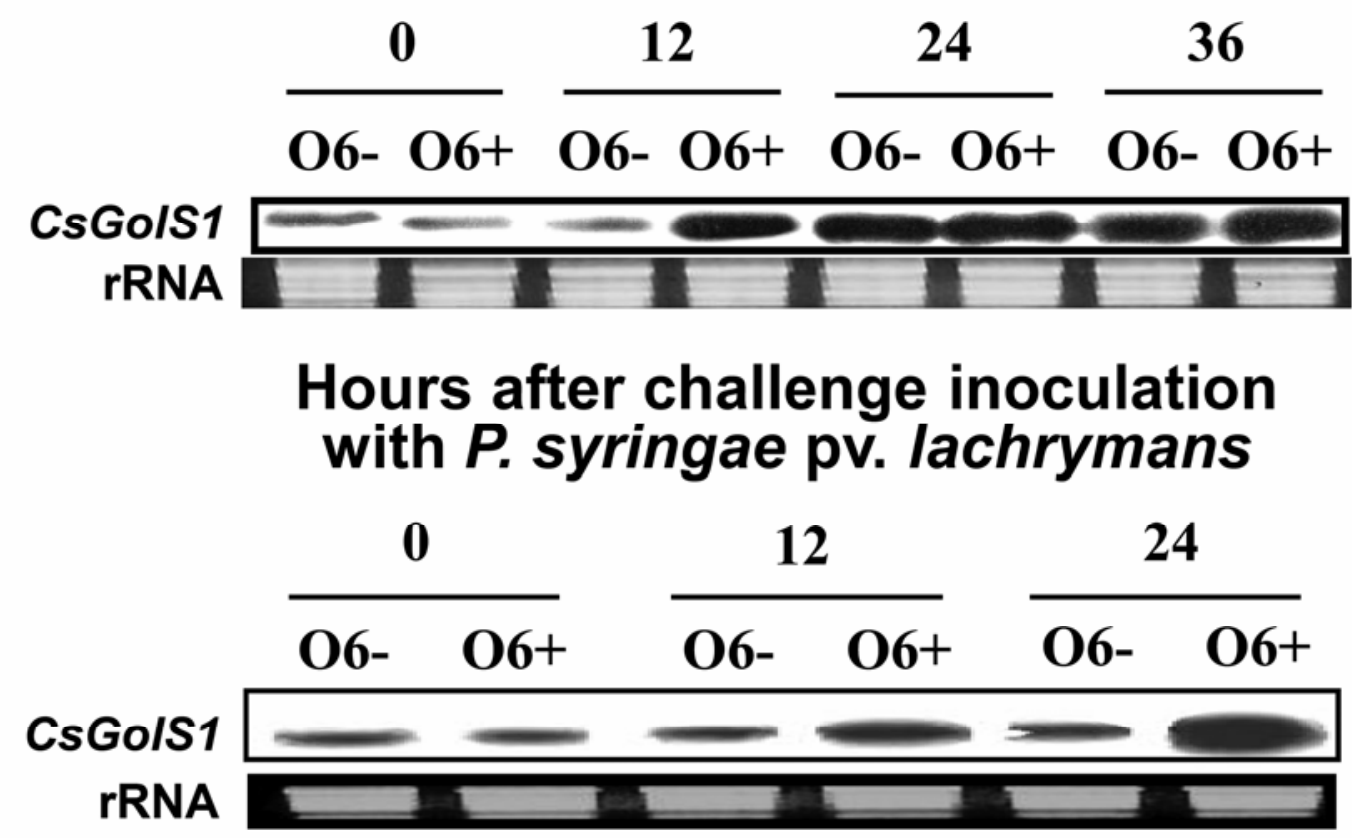

B
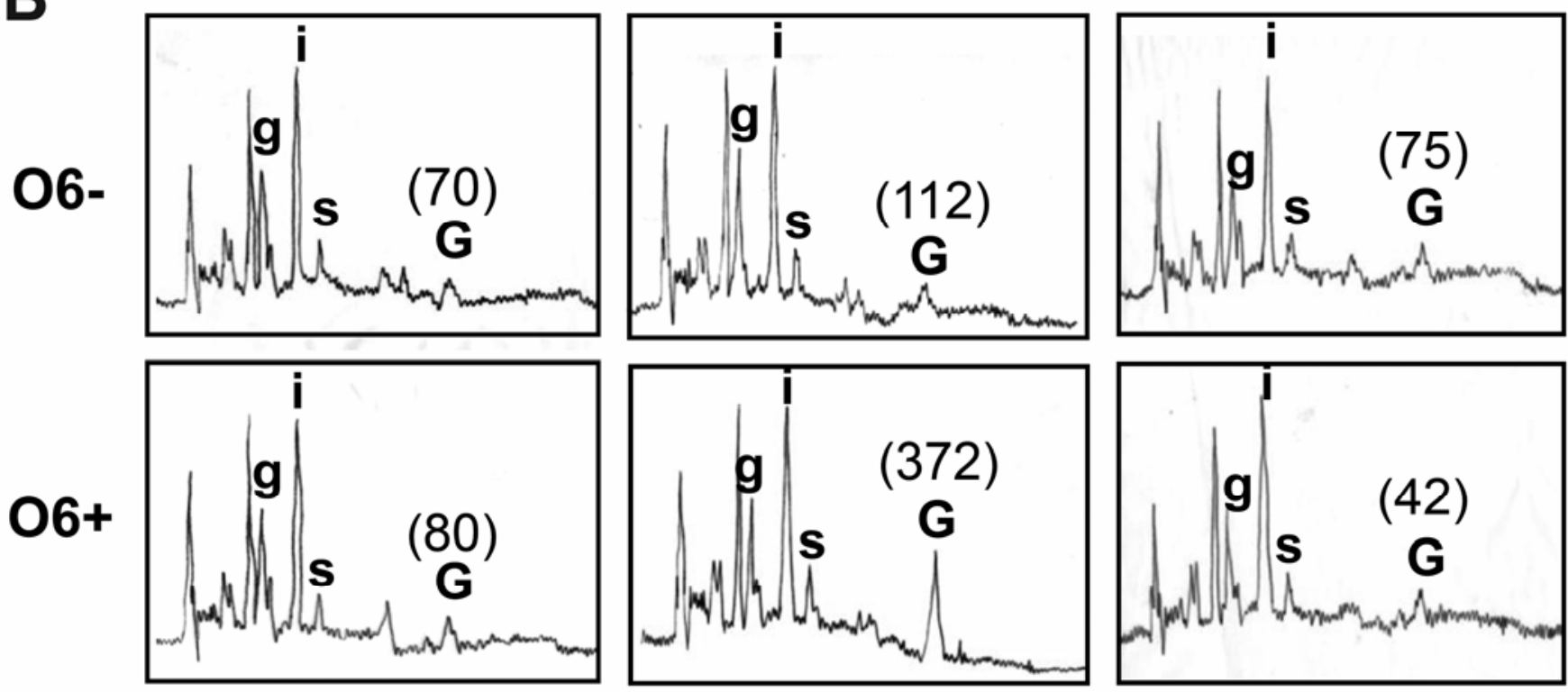

0

12

24

Hours after challenge inoculation with C. cassiicola

g: Glucose i: Myo-inositol s: Sucrose
G: Galactinol (Content: $\left.\mu \mathrm{g} \mathrm{g}^{-1} \mathrm{FW}\right)$

Fig. 1. A, Differential expression of the CsGolS1 gene in cucumber leaves with (O6+) and without (O6-) Pseudomonas chlororaphis O6 colonization on the roots $0,12,24$, and $36 \mathrm{~h}$ after challenge inoculation with Corynespora cassiicola or with P. syringae pv. lachrymans. Expression pattern of the CsGolS1 gene was determined by Northern hybridization using a gene-specific DNA probe. B, High-performance liquid chromatography (HPLC) profiles of some carbohydrate metabolites purified from cucumber leaves with (O6+) and without (O6-) strain O6 colonization on roots 0,12 , and $24 \mathrm{~h}$ after challenge inoculation with $C$. cassiicola. The number in parentheses above the $\mathrm{G}$ letter is the galactinol content ( $\mu \mathrm{g} \mathrm{g}^{-1}$ fresh weight) quantified from the HPLC profile. 
independent transgenic $\mathrm{T}_{1}$ lines that showed an increased expression of the CsGolS1 gene compared with wild-type and vector-only plants. The four $\mathrm{T}_{1}$ lines were morphologically indistinguishable from the wild-type plants and showed endogenous levels of galactinol approximately 6- to 10-fold higher than that of wild-type plants (Fig. 2A). In order to evaluate the range of protection offered by overexpression of the CsGolS1 gene, we examined selected $\mathrm{T}_{1}$ lines for disease resistance to fungal pathogen Botrytis cinerea and to bacterial pathogen E. carotovora subsp. carotovora of tobacco. After pathogen inoculation, survival rates were assessed by determining the number of symptomatic plants per pot. Increased accumulation of galactinol content by the stable integration of the CsGolS1 gene into the tobacco genomes conferred disease resistance constitutively against both $B$. cinerea and $E$. carotovora. At 3 to 5 days after inoculation with $B$. cinerea, the CsGolS1 overexpressors clearly showed more resistance to the pathogen infection (40 to $63 \%$ increase in the survival rate) compared with wild-type plants, although some variation was shown among the $T_{1}$ lines (Fig. 2B). We also examined the responses of the transgenic tobacco against infection with $E$. carotovora to estimate the functional role of this gene in the bacterial disease resistance. Infection of wild-type tobacco with the bacterial pathogen destroyed approximately $93 \%$ plants ( $7 \%$ survival rate), whereas 51 to $72 \%$ of the transgenic tobacco plants survived the bacterial infection (Fig. 2B).

Pharmaceutical application of galactinol protects tobacco plants from pathogen infection and induces the expression of defense-related genes.

If disease resistance is enhanced in the transgenic tobacco plants when the endogenous levels of galactinol are increased, one would expect that exogenous galactinol treatment should be active in protecting wild-type tobacco plants against pathogen infection. To test this hypothesis, purchased galactinol was tested for its ability to enhance resistance to bacterial and fungal infections on wild-type tobacco plants. As controls, plants were treated with distilled water or with other disaccharides (negative control) such as sucrose and lactose. Feeding galactinol to wildtype tobacco plants through the root system in Murashige-Skoog (MS) agar resulted in a significant disease resistance on the upper portions of the plant. In order to find the optimum concentration of exogenously treated galactinol, various levels of galactinol (from 0.1 to $10 \mathrm{mM}$ ) were applied onto the plant roots of wild-type tobacco seedlings growing in MS agar. The most effective concentration in terms of survival rate against $E$. carotovora infection was seen at $0.5 \mathrm{mM}$ (Fig. 3A). Galactinol feeding of wild-type tobacco through the root system in MS agar resulted in fungal resistance on the upper portions of the plant. When $0.5 \mathrm{mM}$ galactinol was applied to tobacco roots and the upper portions of the plants were subsequently challenged with $B$. cinerea, the disease lesion area caused by the fungus was reduced significantly when compared with water-treated plants (Fig. 3B). However, there was a limitation in differentiating the induced resistance between galactinol and the other disaccharides by measuring the disease lesion areas. On the other hand, when $0.5 \mathrm{mM}$ galactinol was applied to tobacco roots and then upper portions of the plants were subsequently challenged with $E$. carotovora, the disaccharide galactinol clearly conferred enhanced disease resistance against the pathogen infection compared with distilled water or other disaccharide controls. (Fig. 3C). These outcomes in conjunction with the above results allow us to prove that galactinol treatment induces disease resistance in plants against fungal and bacterial pathogens, and the galactinol-mediated induction is not due to the osmotic effect that can be possibly caused by such sugar treatment.
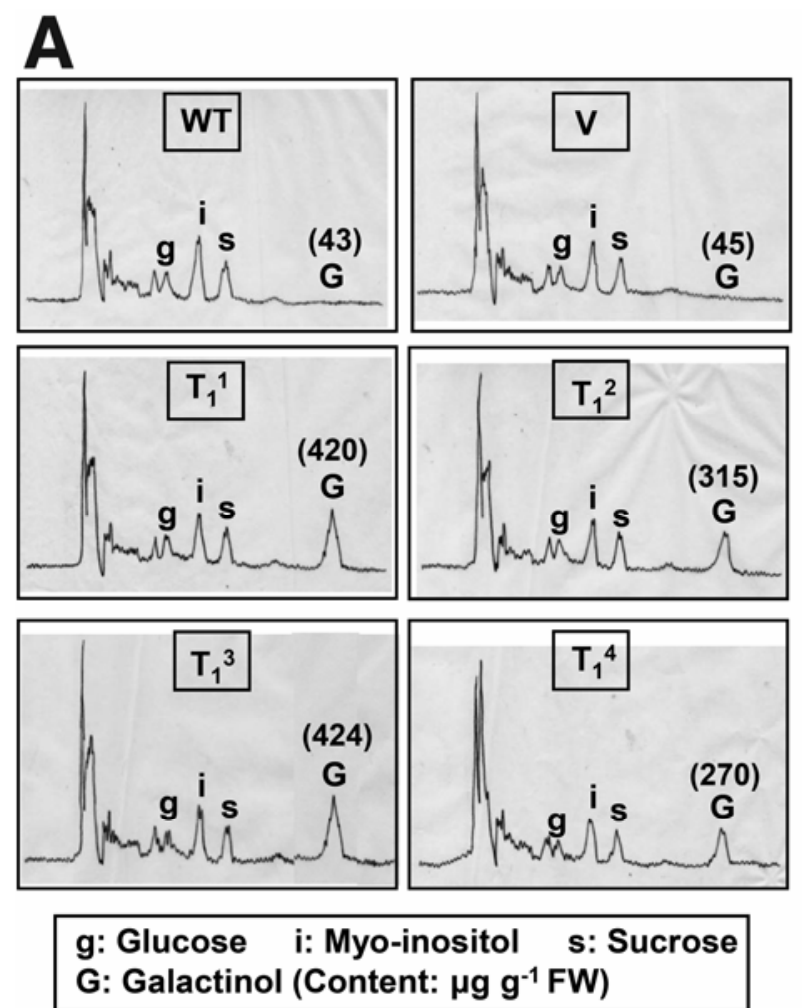
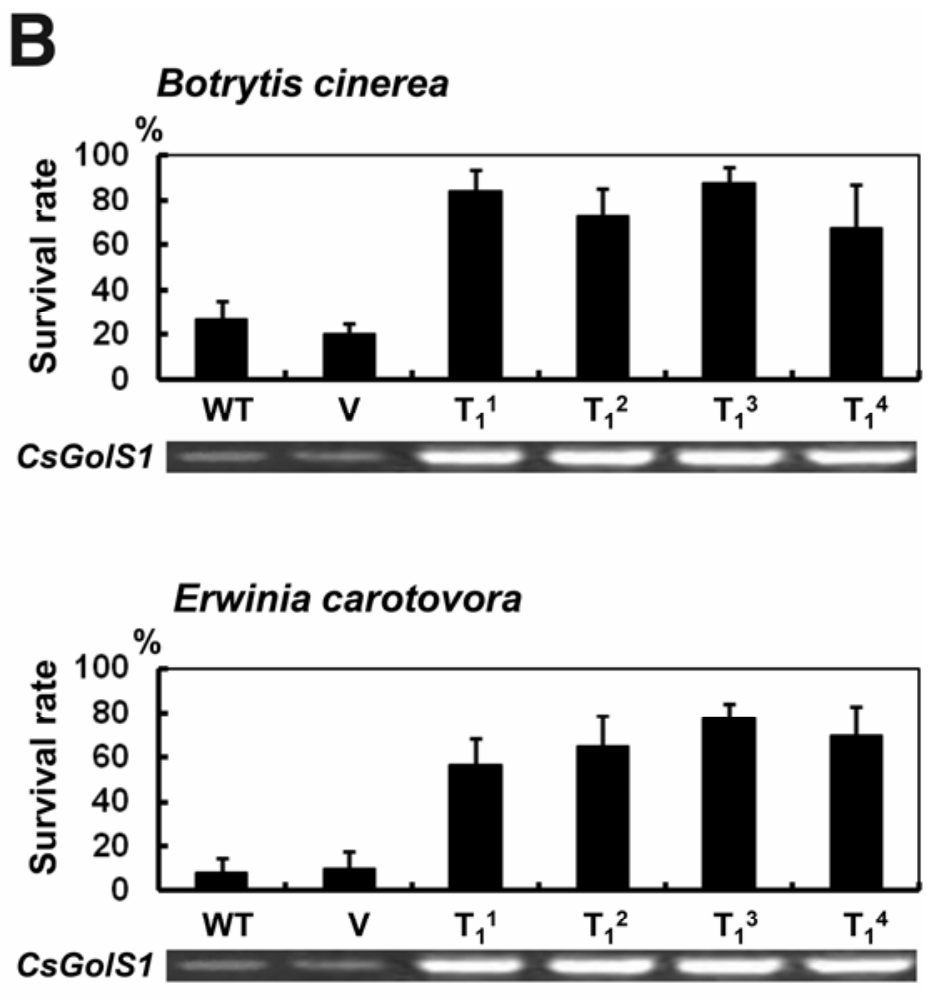

Fig. 2. A, High-performance liquid chromatography (HPLC) profiles of some carbohydrate metabolites purified from the CsGolS1-overexpressing transgenic tobacco tissue. The number in parentheses above the $\mathrm{G}$ letter is the galactinol content $\left(\mu \mathrm{g} \mathrm{g}^{-1}\right.$ fresh weight) quantified from the HPLC profile. WT: wild type, $\mathrm{V}$ : vector only, $\mathrm{T}_{1}{ }^{1}, \mathrm{~T}_{1}{ }^{2}, \mathrm{~T}_{1}{ }^{3}$, and $\mathrm{T}_{1}{ }^{4}$ : four independent $\mathrm{T}_{1}$ lines. $\mathbf{B}$, Increase in survival rate of the CsGolS1-overexpressing tobacco $\mathrm{T}_{1}$ lines against pathogen infections. Five-week-old transgenic plants grown on soil in pots were infected with Botrytis cinerea or Erwinia carotovora. Vertical bars indicate \pm standard deviation. 
The increase of galactinol content in plant leaves, both endogenously through the transgene expression and exogenously through the sugar treatment, conferred disease resistance against bacterial and fungal infections. These findings support the theory that galactinol may function as a signaling molecule for induction of disease resistance. In order to test this hypothesis, we decided to investigate the galactinol responsiveness of those defense-related genes such as PRla, PRIb, Nicotiana tabacum 1-aminocyclopropane-1-carboxylic acid synthase 1 (NtACS1), and N. tabacum 1-aminocyclopropane-1carboxylic acid synthase 2 (NtACS2). Feeding of $0.5 \mathrm{mM}$ galactinol through the root system resulted in an increased accumulation of defense-related gene transcripts in the leaves of wildtype tobacco (Supplemental Fig. 1). Because the level of transcript accumulation by $0.5 \mathrm{mM}$ galactinol treatment was relatively low, the expression of the defense-related genes altered by $5 \mathrm{mM}$ galactinol treatment was investigated. The pattern of increased transcript accumulation after treatment with $5 \mathrm{mM}$ galactinol was very similar to the results obtained by $0.5 \mathrm{mM}$ galactinol. The $5 \mathrm{mM}$ galactinol treatment through the root system induced PRIa, PRIb, and NtACS1 gene expression but failed to induce NtACS2 gene expression in the leaves of wildtype tobacco plants (Fig. 4). This suggested that galactinol might be a signaling component of the defense response to challenging pathogens.

\section{Galactinol-enhanced tolerance}

\section{to drought and high-salinity stresses.}

Taji and associates (2002) demonstrated that overexpression of AtGolS2 resulted in enhanced accumulation of endogenous level of galactinol and raffinose and improved drought tolerance in transgenic Arabidopsis. These results indicate that galactinol has a function in drought-stress tolerance in plants. Expression analysis of the CsGolS1 gene under various abiotic stress conditions revealed that drought and high-salinity conditions strongly induced transcription of this gene in cucumber plants (data not shown). In accordance with the result of Taji and associates (2002), the increased level of galactinol in the CsGolS1-transgenic tobacco conferred a high level of tolerance to drought and high salinity (250 mM NaCl) (Fig. 5A). Feeding galactinol to wild-type tobacco plants through the root system in MS agar also resulted in tolerance of the upper portions of the plant to drought and high-salinity conditions (Fig. 5B). Therefore, an increase in the endogenous level of galactinol can protect plants both from biological attacks by pathogens and from damages caused by environmental stresses.

\section{DISCUSSION}

Plants resist pathogen attacks by virtue of a broad range of defense mechanisms. Many inducible defense responses are involved in the expression of host resistance, which suggests that they can be elicited by both parasite-specific and nonspecific signals (Hammond-Kosack and Jones 2000; Heath 2000; Mysore and Ryu 2004). Inducible defenses can be activated in plants upon the recognition of pathogen-derived cell wall fragments, including microbial $\beta$-(1,3)-glucans and chitin-derived oligomers (Boller 1995; Ebel 1998; Ebel and Mithöfer 1998; Nürnberger et al. 2004). Inducible defense responses are also elicited by host cell wall fragments (including the plant pectin fragments) released during pathogen attack. The fragments perform important functions in plants as signaling molecules involved in the recognition of pathogen attack (Côté and Hahn 1994; Ebel 1998; Ebel and Mithöfer 1998). Many such exogenous cell wall fragments have been shown to be poly- or oligosaccharides. $\alpha-(1,4)$-Oligogalacturonides (OG) derived from the plant cell wall during pathogen attack are well-known elicitors of defense responses (Côté and Hahn 1994; Ridley et al. 2001). Although the majority of defense responses elicited by $\mathrm{OG}$ require a degree of polymerization (DP) between 10 and 15, smaller oligomers with a DP of 2 to 8 have also been shown to activate defense responses (Weber et al. 1996; Wegener et al. 1996), ET production (Simpson et al. 1998), the elicitation of genes involved in JA synthesis (Norman et al. 1999), and the accumulation of protease inhibitors (Moloshok et al. 1992). In our study, an increase in the endogenous galactinol level, a disaccharide responsible for the synthesis of RFO, enhanced the resistance of plants against fungal and bacterial
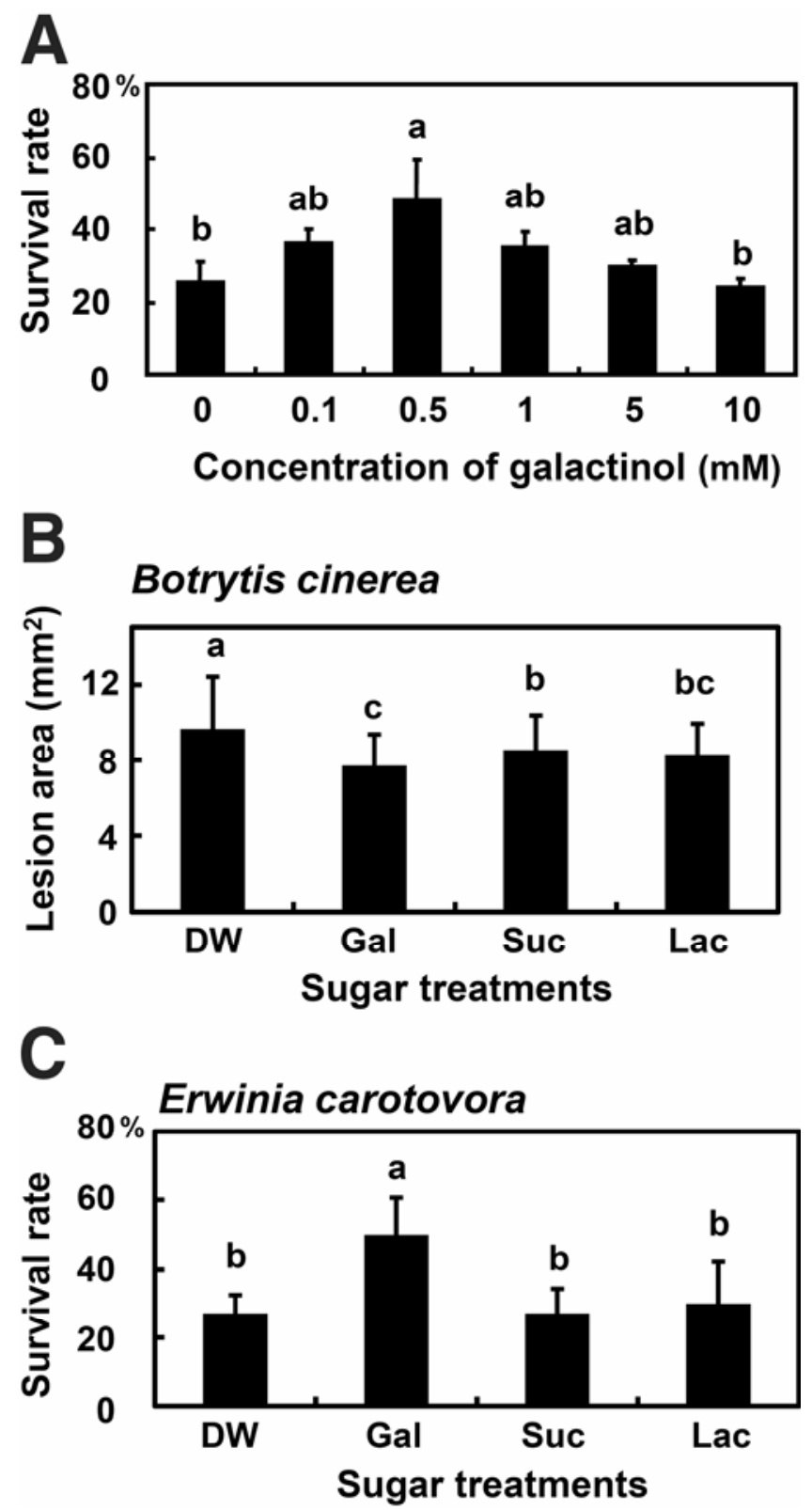

Fig. 3. Induction of resistance in the upper portion of wild-type tobacco against infection with Botrytis cinerea and Erwinia carotovora by $0.5 \mathrm{mM}$ galactinol feeding through the plant root system in Murashige-Skoog (MS) agar. A, Optimum concentration of galactinol in MS agar for the increase in survival rate against $E$. carotovora. $\mathbf{B}$, Resistance against $B$. cinerea was quantified by measuring the disease lesion area formed 3 days after inoculation. The inoculation was conducted by pipetting $5 \mu \mathrm{l}$ of the conidial suspensions $\left(2.5 \times 10^{5}\right.$ spores $\left./ \mathrm{ml}\right)$ onto each leaf. C, Resistance against $E$. carotovora was quantified by the survival rate. Vertical bars indicate \pm standard deviation. Bars with different letters denote a significant difference $(P \leq 0.05) . \mathrm{DW}=$ distilled water, $\mathrm{Gal}=$ galactinol, Suc $=$ sucrose, $\mathrm{Lac}$ $=$ lactose. 
infections. Our results show that the endogenous synthetic oligosaccharides in the anabolic pathway for RFO (Sprenger and Keller, 2000), including galactinol, can perform important functions as signaling molecules and elicit defense responses against pathogen attack. Pretreatment of rice plants with sucrose enhanced resistance to Magnaporthe oryzae infection, and this suggests that sucrose may act as an endogenous molecular signal for induction of defense responses (GómezAriza et al. 2007). However, exogenous sucrose treatment did not protect wild-type tobacco plants against bacterial infections in this experiment (Fig. 3C). Further investigations should be conducted regarding the reason for this result. This may be a simple matter of plant difference (mono- and dicotyledonous), pathogen difference (fungal and bacterial), or the concentration of the applied sugar because galactinol demonstrated an optimum concentration for the induction of resistance.

Since Wei and associates (1991) and Van Peer and associates (1991) reported that certain strains of rhizobacteria activate the plant defense responses against fungal pathogens Colletotrichum orbiculare and Fusarium oxysporum, a variety of studies have also reported this elicitation of ISR-mediated plant defense. The application of the rhizobacterium $P$. chlororaphis $\mathrm{O} 6$ to the roots elicited ISR in the cucumber and tobacco plants against different fungal and bacterial pathogens (Kim et al. 2004; Spencer et al. 2003). ISR-expressing plants have been shown to be primed for the augmented expression of a specific set of pathogen-responsive genes (Conrath et al. 2002; Verhagen et al. 2004). Cucumber plants colonized with $P$. chlororaphis O6 were also primed against Corynespora cassiicola infection and demonstrated an augmented expression of identified CsISR genes, including a galactinol synthase ( $C s G o l S 1)$ gene. The transcription of the CsGolS1 gene was accelerated by the priming process (Fig. 1A) and the accumulation of the gene transcript coincided with increased galactinol levels in the challenge-inoculated leaves (Fig. 1B). However, the accelerated accumulation of galactinol observed $12 \mathrm{~h}$ after the challenge inoculation diminished very rapidly and fell back to basal levels within $12 \mathrm{~h}$. These results imply that the accelerated accumulation of galactinol can function transiently as a signaling molecule during the initial interaction between primed plant leaves and fungal penetration. Galactinol synthase catalyzes the formation of galactinol from UDP-galactose and myoinositol (Sprenger and Keller 2000). Hence, the enhanced activity of the enzyme in O6-mediated ISR will likely exert an effect on the inositol 1,4,5-trisphosphate (IP3) cycle and the phospholipid composition of the plasma membrane. Phosphoinositide-specific phospholipase $\mathrm{C}$ was activated transiently but IP3 contents were shown to have been reduced in soybean cells infected with the bacterial pathogen $P$. syringae pv. glycinea (Shigaki and Bhattacharyya 2000). This suggested that reduced IP3 content following infection may result in the suppression of various cellular housekeeping activities, thus diverting the cellular resources either to the synthesis of defenserelated compounds or to pathogen growth.

The RFO consist of galactose units linked to sucrose via $\alpha$ $(1,6)$ glycosidic linkages (Peterbauer et al. 2001). Galactinol synthase (GolS) (EC 2.4.1.123) catalyzes the synthesis of galactinol ( $o-\alpha$-D-galactopyranosyl-(1,1)-1-myo-inositol) from UDPD-galactose and myo-inositol (Sprenger and Keller 2000). Aside from its known functions as a galactosyl donor that synthesizes RFO and operates as an osmoprotectant in response to drought stress (Taji et al. 2002), an enhanced level of galactinol content in plant leaves was demonstrated in this study to signal the induction of disease resistance against pathogens. Galactinol fed hydroponically to tobacco seedlings induced expression of tobacco defense response genes such as PRla (SA-dependent) (Ryals et al. 1996), PRIb (JA- or ET-dependent) (Thomma et al.1998), and NtACS1 (ET-dependent) (Chen et al. 2003) in leaves (Fig. 4). Colonization by the $P$. chlororaphis $\mathrm{O} 6$ caused increased accumulation for transcripts of regulated tobacco de-
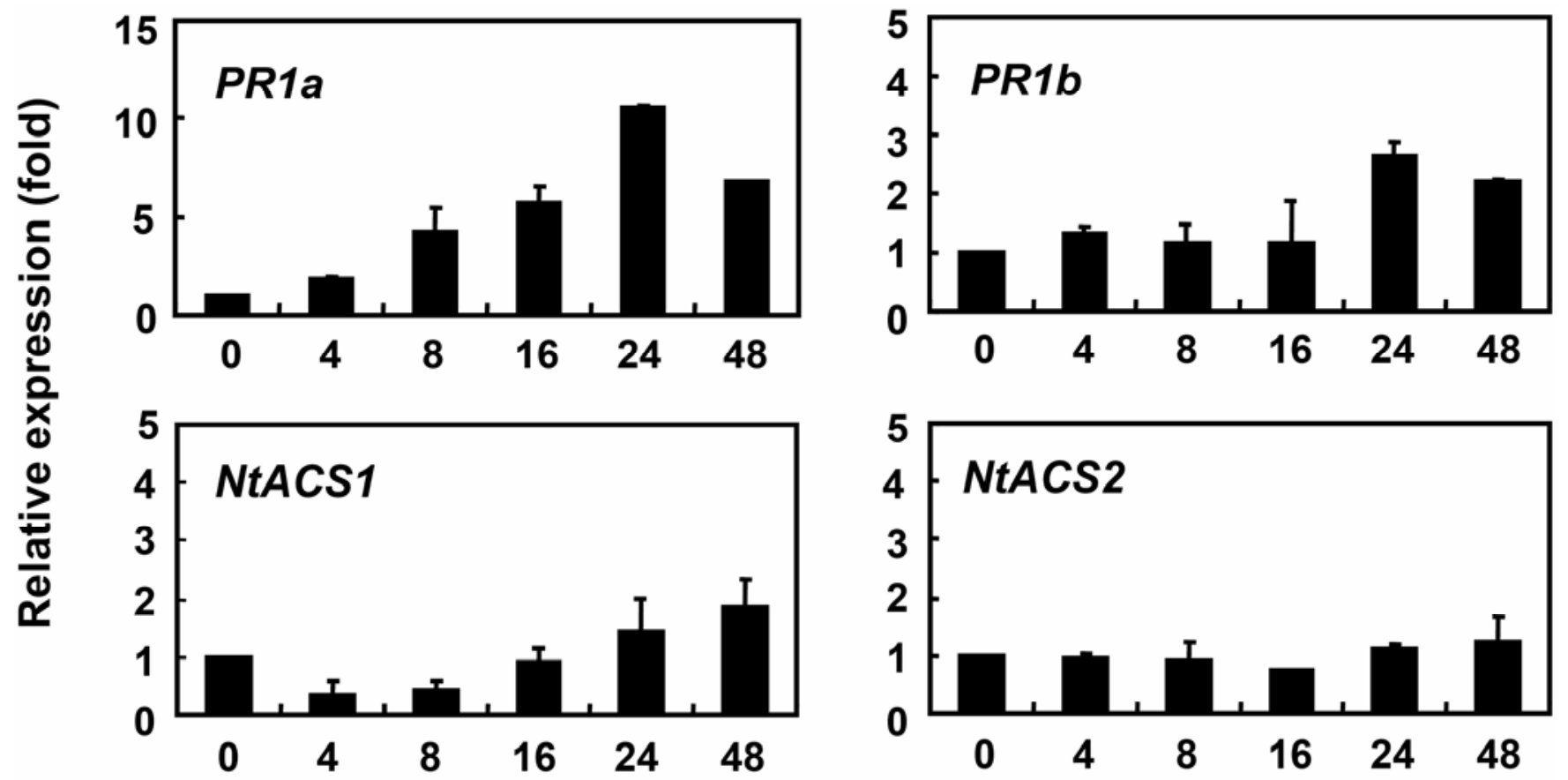

Hours after galactinol treatment

Fig. 4. Expression kinetics of defense-related genes (PRIa, PR1b, NtACS1, and NtACS2) in the upper portion of wild-type tobacco, by feeding galactinol of $5 \mathrm{mM}$ through the plant roots. Gene expression was analyzed by real-time reverse-transcription polymerase chain reaction $0,4,8,16,24$, and $48 \mathrm{~h}$ after the sugar treatment on the plant root. The specific primer set was used to detect the expression pattern of each gene. Vertical bars indicate \pm standard deviation. 
fense genes such as $P R-1 g, H M G R$, and $L O X$ but no accumulation of transcript of the $P R-1 a$, a typical marker of SA-mediated responses (Spencer et al. 2003). Therefore, it was suggested that strain O6 may activate the JA or ET plant defense pathways but not an SA-dependent signaling pathway. On the other hand, treatment of tobacco plants with galactinol induced not only $P R I b$ and NtACS2 gene expressions that are for JA and ET path- ways but also $P R$-la gene expression for SA pathway in this experiment (Fig. 4). The reason that the reaction to the $P R-1 a$ gene is different in the above two experiments can be explained like this. Recently, we demonstrated that root colonization of Arabidopsis with the strain O6 induces tolerance to drought stress. Increases in free SA after drought stress of the strain O6colonized plants suggested a primary role for SA signaling in
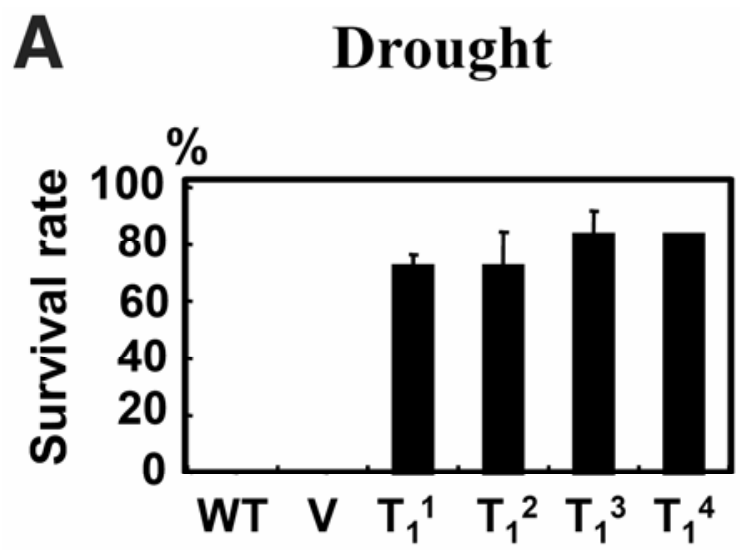

CsGols1

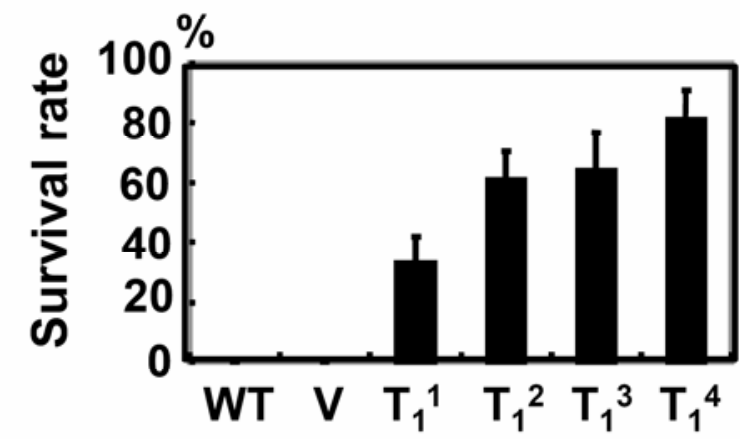

CsGols1
High salinity

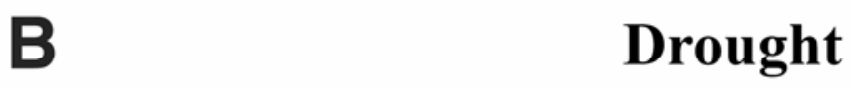

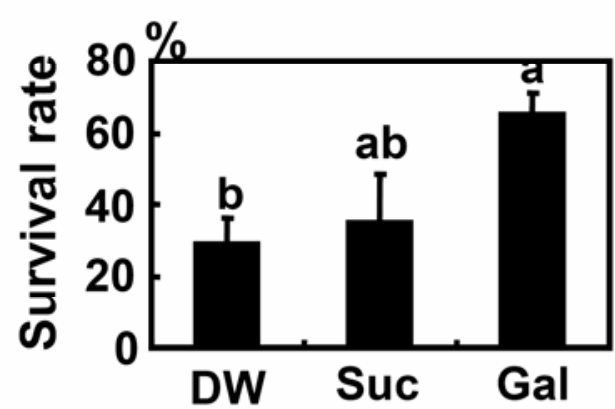

Sugar treatment

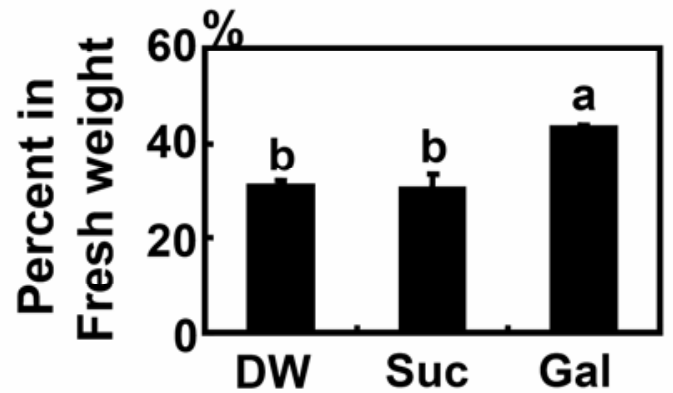

Sugar treatment

\section{High salinity}

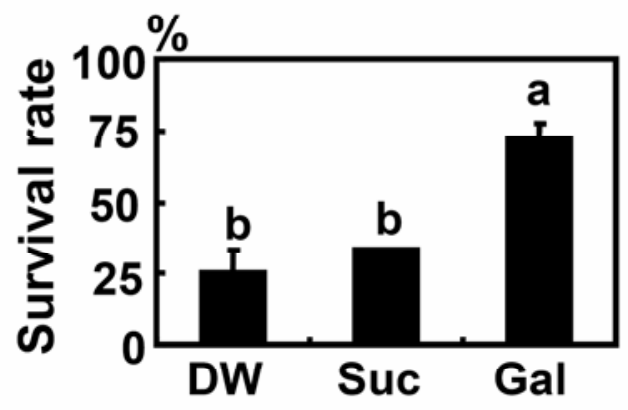

Sugar treatment

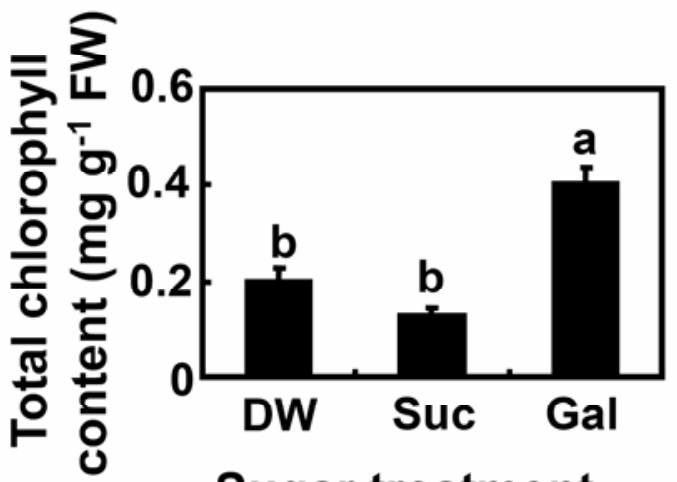

Sugar treatment

Fig. 5. A, Increase in survival rate of the CsGolS1-overexpressing transgenic tobacco $\left(\mathrm{T}_{1}\right)$ lines against drought and high-salinity stresses. Five-week-old transgenic plants grown on soil in pots were soaked in $250 \mathrm{mM} \mathrm{NaCl}$ solution for high-salinity treatment. For drought treatment, water was withheld from plants until they showed visible wilting. WT: wild type, $\mathrm{V}$ : vector only, $\mathrm{T}_{1}{ }^{1-4}$ : four independent $\mathrm{T}_{1}$ lines. B: Induction of tolerance in the upper portion of wild-type tobacco against drought and high-salinity stresses by $0.5 \mathrm{mM}$ galactinol feeding through the root system in MS agar. The induced tolerance was quantified by the survival rate and percent fresh weight $(\%)$ for drought stress, and by the survival rate and total chlorophyll content for high salinity in the same plant. Vertical bars indicate \pm standard deviation. Bars with different letters denote a significant difference $(P \leq 0.05)$. DW: distilled water, Suc: sucrose, Gal: galactinol. 
induced drought tolerance (Cho et al. 2008). Because galactinol treatment also induces drought tolerance (Fig. 5), it is not surprising that the treatment also induced the expression of the $P R-1 a$ gene in this experiment.

These findings suggest that a high level of endogenous galactinol may be responsible for the earlier and stronger expression of the tobacco defense genes. The fact may retroactively suggest that $P$. chlororaphis O6-mediated priming in cucumber leaves against challenging pathogens is linked to galactinol signaling. Definitive proof that galactinol has a role in disease resistance in plants comes from results obtained in disease resistance studies with galactinol-treated tobacco plants (Fig. $3)$. This observation confirms the implication that galactinoldependent defense responses function in the protection of tobacco against $B$. cinerea and E. carotovora, and supports the idea that galactinol-mediated priming of defense responses in cucumber plants results in disease resistance against $C$. cassiicola and $P$. syringae pv. lachrymans. In this context, our results suggest that galactinol acts as an endogenous molecular signal for induction of defense responses in plants. Kenfield and Strobel (1981) showed that naturally occurring galactinol and raffinose binds to $\alpha$-galactoside-binding proteins isolated from the cellular membranes of plants. Such binding proteins can be involved in defense responses, and the characterization of the proteins will be an essential first step in clarifying the mechanisms underlying galactinol-mediated ISR.

\section{MATERIALS AND METHODS}

\section{Rhizobacterial inoculation on cucumber seed.}

The rhizobacterium $P$. chlororaphis $\mathrm{O} 6$ was grown on King's medium B (KB) agar plates for $24 \mathrm{~h}$ at $28^{\circ} \mathrm{C}$. The bacterial cells were subsequently collected and resuspended in $0.02 \mathrm{M}$ phosphate buffer ( $\mathrm{pH} 7.0)$ and then an equal volume of $2 \%$ methylcellulose (Sigma, St. Louis) was added. The bacterial suspension was mixed with cucumber seed (Cucumis sativus L., cv. Baekseong), resulting in $5 \times 10^{8}$ to $1 \times 10^{10} \mathrm{CFU} / \mathrm{seed}$, and was air dried overnight in a laminar flow hood (Raupach and Kloepper 1998). Prior to mixing with strain O6, the cucumber seed were surface sterilized with a solution of $10 \%$ hydrogen peroxide in order to eliminate seed-infesting organisms. Each cucumber seed coated with the O6 strain was planted to a depth of approximately $1 \mathrm{~cm}$ in a $10-\mathrm{cm}^{2}$ polyvinyl pot containing $500 \mathrm{~cm}^{3}$ of sterilized soilless growing medium (peat moss:vermiculite, 7:3). The plants were cultivated in a growth chamber with a light and dark cycle of 10 and $14 \mathrm{~h}(25$ and $20^{\circ} \mathrm{C}$ ), respectively, at $70 \%$ relative humidity, with daily watering. One week after sowing, when the cotyledons had sprouted, $20 \mathrm{ml}$ of the rhizobacterial suspension $\left(1 \times 10^{8}\right)$ in sterile water was applied once around the seedling in each pot.

\section{Inoculation of cucumber plants with the pathogen.}

Four-week-old cucumber plants in pots were challenge inoculated with Corynespora cassiicola by spraying a conidial suspension of the fungus at a concentration of $5 \times 10^{4}$ spores $/ \mathrm{ml}$ of sterile water, and were maintained for $12 \mathrm{~h}$ in a growth chamber at $100 \%$ relative humidity. The fungus was grown on Czapek solution agar (Difco, Detroit) plates for 2 weeks at $28^{\circ} \mathrm{C}$ in an incubator. The aerial mycelia were removed by gently rubbing the surface with a writing brush in tap water and the samples were then air dried in a laminar flow hood. In order to produce the conidia, the plates were positioned in an incubator for 1 week at $28^{\circ} \mathrm{C}$ with illumination by fluorescent lamps (approximately 2,000 Lux). Four-week-old cucumber plants were challenge inoculated with $P$. syringae pv. lachrymans by spraying with a bacterial suspension of $1 \times$ $10^{8} \mathrm{CFU} / \mathrm{ml}$. The bacterial cells were grown at $28^{\circ} \mathrm{C}$ with shaking at $200 \mathrm{rpm}$ in Luria-Bertani (LB) broth to an optical density at $600 \mathrm{~nm}$ of 2.0, centrifuged, and resuspended in sterile water.

\section{Tobacco transformation.}

The sense CsGolS1 DNA of cucumber was synthesized by PCR using two synthetic primers, left 5' GCTCTAGAAAGTT AATATGTCTCC 3' (XbaI restriction site underlined) and right 5' GGGGTACCATATACTTAAGCAGCAGA 3' (KpnI restriction site underlined), and using the CsGolS1 cDNA as a template. The CsGolS1 DNA was cloned into the predigested binary vector, $\mathrm{pBI} 121$, replacing the $\beta$-glucuronidase gene. Tobacco ( $N$. tabacum cv. Xanthi) was transformed by the leaf-disk method using Agrobacterium tumefaciens LBA4404 containing the CsGolS1 recombinant plasmid. Individual kanamycin-resistant regenerated shoots were selected, and the plants were rooted in MS medium with no growth regulators and then transferred to soil. $\mathrm{T}_{1}$ seed resulting from self-pollination were aseptically germinated in continuous light $(2,000 \mathrm{lux})$ at $26^{\circ} \mathrm{C}$ on MS medium supplemented with kanamycin at $200 \mu \mathrm{g} / \mathrm{ml}$.

\section{Northern blot and RT-PCR analyses.}

Total RNA $(20 \mu \mathrm{g})$ was extracted from the cucumber after inoculation with the corresponding pathogen by the Phenol/ $\mathrm{SDS} / \mathrm{LiCl}$ method, separated on $1.2 \%$ formaldehyde/agarose gel, and subsequently transferred onto a nylon membrane. The specific expression pattern of the CsGolS1 gene in the cucumber was measured by Northern hybridization using a DNA fragment of approximately $400 \mathrm{bp}$, which included the 3' untranslated region of the cDNA. The DNA fragment was amplified by PCR using a synthetic forward primer (5'-gaagttgtcaac cacatc- $3^{\prime}$ ) and an oligo (dT) primer as the reverse. The RNA blot was hybridized with the $\mathrm{P}^{32}$-labeled cDNA probe and washed at a high stringency. Hybridization and $\mathrm{P}^{32}$-labeling of cDNA were conducted in accordance with the standard procedures (Sambrook et al. 1989). For RT-PCR analysis, $500 \mathrm{ng}$ of total RNA extracted from transgenic tobacco tissue by the Phenol/ $\mathrm{SDS} / \mathrm{LiCl}$ method was used along with the CsGolS1 gene-specific primer (forward, 5'-TGCTGGTGAAGAAATGGT-3'; reverse, 5'-GCAGAAGGAAGCGTGATG-3'). The gene was amplified via $35 \mathrm{PCR}$ cycles at $94^{\circ} \mathrm{C}$ for $39 \mathrm{~s}, 55^{\circ} \mathrm{C}$ for $1 \mathrm{~min}$, and $72^{\circ} \mathrm{C}$ for $1 \mathrm{~min}$.

\section{Sugar analysis by HPLC.}

Plant cell extracts were prepared from cucumber and transgenic tobacco tissues. Each plant tissue was frozen with liquid nitrogen, crushed, added to $20 \mathrm{ml}$ of $50 \%$ methanol, and shaken for $1 \mathrm{~h}$. The apparatus utilized for HPLC analysis was an LC 2000 series (Jasco, Tokyo) coupled with an evaporative light scattering detector (ELSD) 200 (SofTA, Broomfield, CO, U.S.A.). An ELSD nitrogen generator was employed as a source of nitrogen gas. Separation was conducted at $30^{\circ} \mathrm{C}$ on a reversed-phase Shim-pack CLC- $\mathrm{NH}_{2}$ column (6 by $150 \mathrm{~mm}$ ). ELSD conditions were optimized for maximum sensitivity: the spray chamber temperature was set at $35^{\circ} \mathrm{C}$ and the drift tube temperature was set to $60^{\circ} \mathrm{C}$. The mobile phase was $70 \%$ acetonitrile, which was maintained at a constant flow-rate of 1 $\mathrm{ml} / \mathrm{min}$, and the injection volume was $40 \mu \mathrm{l}$. The carbohydrates were determined quantitatively via the comparison of peak areas of the chromatograms with those of the standards.

\section{Disease assessment on tobacco plants.}

Five-week-old tobacco plants grown on soil in pots were inoculated with $B$. cinerea 4709 by spraying suspensions of $3.5 \times 10^{4}$ spores $/ \mathrm{ml}$ of potato dextrose broth (PDB). Inoculated plants were kept in a growth chamber at $100 \%$ relative humidity for $24 \mathrm{~h}$. Four to six days after inoculation, survival rate 
was assessed by determining the number of symptomatic plants per pot. Six independent experiments were performed, with at least 50 plants per treatment. The fungus was grown on a potato dextrose agar (PDA) (Difco) plate for 2 weeks at $25^{\circ} \mathrm{C}$ in an incubator and the inoculum was then transferred to a onehalf PDA plate, where it was further incubated for 1 week at $25^{\circ} \mathrm{C}$ in an incubator. To produce spores, the plates were again placed in an incubator for 2 days at $25^{\circ} \mathrm{C}$ with fluorescent illumination (approximately 2,000 Lux). Five-week-old tobacco plants cultivated on soil in pots were inoculated with E. carotovora $\mathrm{SCC} 1$ by spraying the bacterial suspension at a concentration of $1 \times 10^{8} \mathrm{CFU} / \mathrm{ml}$ onto the leaves. One to two days after inoculation, soft rot disease was rated by counting the number of symptomatic plants per pot. Six independent experiments were performed, with at least 50 plants per treatment.

\section{Application of galactinol and disease assessment on tobacco plants grown in MS agar.}

Galactinol dehydrate (Fluka 79544, purum grade, $\geq 98.0 \%$ [HPLC]) was purchased from Fluca Co. (Buchs, Sweden). In order to find the optimum concentration for application, sterile galactinol solution at concentrations of $0,0.1,0.5,1,5$, and 10 $\mathrm{mM}$ were used to treat tobacco plants growing in sterilized growing medium. Tobacco seed were placed on MS agar supplemented with $1.5 \%$ sucrose in each well of a 12 -well microtiter plate (SPL, Pocheon, Korea). Two weeks after the plants were seeded in the microtiter plate, $20 \mu \mathrm{l}$ of $0.5 \mathrm{mM}$ galactinol was applied to plant roots on MS agar in each well. At the same time, $20 \mu \mathrm{l}$ of distilled water or $20 \mu \mathrm{l}$ of another disaccharide $(0.5 \mathrm{mM}$ each of sucrose and lactose) was applied to plant roots in separated plates as a control or negative control, respectively. Five days after the treatment, plants were challenged with $B$. cinerea and $E$. carotovoa. In order to demonstrate induced resistance by galactinol treatment against the fungal pathogen, plants were inoculated with $B$. cinerea onto three leaves by pipetting $5 \mu \mathrm{l}$ of the conidial suspensions of 2.5 $\times 10^{5}$ spores/ml of PDB onto each leaf. The extent of symptoms (disease lesion area) caused by the fungus was measured 3 days after inoculation using the image inside software program version 2.32 (Ehwa Optical Co., Seoul, Korea). Three independent experiments were performed, with at least 100 plants per treatment. On the other hand, plants were inoculated with E. carotovora onto two leaves by pipetting $5 \mu \mathrm{l}$ of the bacterial suspension of $8 \times 10^{8} \mathrm{CFU} / \mathrm{ml}$ onto each leaf. Two days after inoculation, soft rot disease was rated by counting the number of symptomatic plants in the microtiter plates (survival rate). Three independent experiments were performed, with at least 100 plants per treatment. A separate experiment was done to verify the effects on the survival rate by the bacterial pathogen. The galactinol-treated plants were challenged with $E$. carotovora onto two leaves by pipetting $5 \mu \mathrm{l}$ of the bacterial suspension of $1 \times 10^{8} \mathrm{CFU} / \mathrm{ml}$ per each leaf.

\section{Real-time RT-PCR.}

Tobacco seed were placed on MS agar supplemented with $1.5 \%$ sucrose in each well of a 12 -well microtiter plate (SPL Korea). Two weeks after the plants were seeded in the microtiter plate, $20 \mu \mathrm{l}$ of $5 \mathrm{mM}$ galactinol was applied to plant roots on MS agar in each well. Total RNA of the upper portion of the galactinol-treated plants was isolated using an RNeasy plant mini kit (cat. no.74904; Qiagen, Chatsworth, CA, U.S.A.) $0,4,8,16,24$, and $48 \mathrm{~h}$ after the sugar treatment. For the detection of the specific RNA transcript, real-time quantification was conducted in a Rotor-Gene 2000 real-time thermal cycling system (Corbett Research, Sydney, Australia) using a QuantiTect SYBR Green RT-PCR kit (Qiagen). The reaction mixture $(25 \mu \mathrm{l})$ contained $500 \mathrm{ng}$ of total RNA, $0.5 \mu \mathrm{M}$ each primer, and appropriate amounts of enzymes and fluorescent dyes, in accordance with the manufacturer's instructions (Qiagen). For the control reaction, no RNA was added to the reaction mixture, resulting in no detectable fluorescence signal from the reaction. A Primer set for the $18 \mathrm{~S}$ ribosomal RNA gene of tobacco plant (forward, 5'-AGGAATTGACGGAAGG GCA-3'; reverse, 5'-GTGCGGCCCAGAACATCTAAG-3') was used as an internal standard. Data were analyzed using the software provided by the manufacture. Primers for defenserelated genes used in this study are as follows: PRla (forward, 5'-CCAATTGGCTGCAGATTGTA-3'; reverse, 5'-AGTTACG CCAAACCACCTGA-3'), PRIb (forward, 5'-ATACTTCTGC AGCGGGAAAC-3'; reverse, 5'-GATCACCGTAGGGACGTT GT-3'); NtACS1 (forward, 5'-ATCCAAACGCTTCAATTTGC3'; reverse, 5'-AATTGTTTCGTTGGCTCCAG-3'), and NtACS2 (forward, 5'-TCCAAGAATGGGTGGTGAAT-3'; reverse, 5'-C TCCAGTTGCTCCTCCACTC-3').

\section{Drought and high-salinity stress treatments and subsequent damage assessment.}

Both the CsGolS1 overexpressing transgenic and galactinoltreated wild-type tobacco plants were used in this experiment. In the experiment with CsGolS1 overexpressing transgenic tobacco, 5-week-old plants grown on soil in pots were soaked in $250 \mathrm{mM} \mathrm{NaCl}$ solution for high-salinity treatment and then cultivated in a growth chamber. Control plants of the same age were soaked in distilled water. For drought treatment, water was withheld from the 5-week-old plants grown on soil in pots until the plants showed visible wilting. Three independent experiments were performed with at least 50 plants per treatment. In the experiment with galactinoltreated wild-type tobacco, plant seed were placed on MS agar supplemented with $1.5 \%$ sucrose in each well of a 12 well microtiter plate. Two weeks after the plants were seeded in the microtiter plate, $20 \mu \mathrm{l}$ of $0.5 \mathrm{mM}$ galactinol was applied to the plant roots on MS agar in each well. At the same time, $20 \mu \mathrm{l}$ of distilled water or of $0.5 \mathrm{mM}$ sucrose was applied to plant roots in separated plates as a negative control and as a disaccharide control, respectively. Five days after the galactinol treatment, plants were then submitted to drought and high-salinity stresses. Plants grown in filter paper on MS agar plate were carefully removed and exposed to drought stress by placing them on an empty petri dish with half of the cover left open. Approximately $2 \mathrm{~h}$ after transposition, the survival rate (as assessed by the naked eye) and the weight of the stressed plant relative to the unstressed plant were quantitatively measured. Three independent experiments were performed, with at least 100 plants per treatment. To assess the relative salinity tolerance, the plants grown in filter paper on MS agar plates were carefully transferred into $250 \mathrm{mM} \mathrm{NaCl}$ solution and maintained for 5 days. The salt tolerance of the plants was estimated by measuring the survival rate and their total chlorophyll content. Three independent experiments were performed, with at least 100 plants per treatment.

\section{Statistical analysis.}

Data were analyzed by analysis of variance using JMP 4.0 software (SAS Institute, Cary, NC, U.S.A.). The significance of the observed effects was determined by Duncan's multiple range test $(P=0.05)$.

\section{ACKNOWLEDGMENTS}

This work was supported by a grant (R11-2001-092-02006-0) from the Korea Science and Engineering Foundation through the Agricultural Plant Stress Research Center at Chonnam National University. 


\section{LITERATURE CITED}

Ayre, B. G., Blair, J. E., and Turgeon, R. 2003. Functional and phylogenetic analyses of a conserved regulatory program in the phloem of minor veins. Plant Physiol. 133:1229-1239.

Bachmann, M., Matile, P., and Keller, F. 1994. Metabolism of the raffinose family oligosaccharides in leaves of Ajuga reptans L. Cold acclimation, translocation, sink to source transition: Discovery of chain elongation enzyme. Plant Physiol. 105:1335-1345.

Blackman, S. A., Obendorf, R. L., and Leopold, A. C. 1992. Maturation proteins and sugars in desiccation tolerance of developing soybean seeds. Plant Physiol. 100:225-230.

Boller, T. 1995. Chemoperception of microbial signals in plant cells. Annu. Rev. Plant Physiol. 46:189-214.

Brenac, P., Horbowicz, M., Downer, S. M., Dickerman, A. M., Smith, M. E., and Obendorf, R. L. 1997. Raffinose accumulation related to desiccation tolerance during maize (Zea mays L.) seed development and maturation. J. Plant Physiol. 150:481-488.

Chen, H., Goodwin, P. H., and Hsiang, T. 2003. The role of ethylene during the infection of Nicotiana tabacum by Colletotrichum destructivum. J. Exp. Bot. 54:2449-2456.

Cho, S. M., Kang, B. R., Han, S. H., Anderson, A. J., Park, J. Y., Lee, Y. H., Cho, B. H., Yang, K. Y., Ryu, C. M., and Kim, Y. C. 2008. 2R,3Rbutanediol, a bacterial volatile produced by Pseudomonas chlororaphis O6, is involved in induction of systemic tolerance to drought in Arabidopsis thaliana. Mol. Plant-Microbe Interact. 21:1067-1075.

Conrath, U., Pieterse, C. M. J., and Mauch-Mani, B. 2002. Priming in plant-pathogen interactions. Trends Plant Sci. 7:210-216.

Côté, F., and Hahn, M. G. 1994. Oligosaccharins: Structure and signal transduction. Plant Mol. Biol. 26:1379-1411.

Downie, B., Gurusinghe, S., Dahal, P., Thacker, R. R., Synder, J. C., Nonogaki, H., Yim, K., Fukanaga, K., Alvarado, V., and Bradford, K. J. 2003. Expression of a galactinol synthase gene in tomato seeds is upregulated before maturation desiccation and again after imbibition whenever radicle protrusion is prevented. Plant Physiol. 131:1347-1359.

Ebel, J. 1998. Oligoglucoside elicitor-mediated activation of plant defense. Bioessays 20:569-576.

Ebel, J., and Mithöfer, A. 1998. Early events in the elicitation of plant defense. Planta 206:335-348.

Gómez-Ariza, J., Campo S., Rufat M., Estopá, M., Messeguer, J., San Segundo, B., and Coca M. 2007. Sucrose-mediated priming of plant defense responses and broad-spectrum disease resistance by overexpression of the maize pathogenesis-related PRms protein in rice plants. Mol. Plant-Microbe Interact. 20:832-842.

Hammond-Kosack, K. E., and Jones, J. D. G. 2000. Response to plant pathogens. Page 1102-1156 in: Biochemistry and Molecular Biology of Plants. B. Buchanan, D. Gruissem, and R. Jones, eds. American Society of Plant Biologists, Rockville, MD, U.S.A.

Heath, M. C. 2000. Nonhost resistance and nonspecific plant defenses. Curr. Opin. Plant Biol. 3:315-319.

Horbowicz, M., and Obendorf, R. L. 1994. Seed desiccation tolerance and storability: Dependence on flatulence-producing oligosaccharides and cyclitols-review and survey. Seed Sci. Res. 4:385-405.

Iavicoli, A., Boutet, E., Buchala, A., and Métraux, J.-P. 2003. Induced systemic resistance in Arabidopsis thaliana in response to root inoculation with Pseudomonas fluorescens CHA0. Mol. Plant-Microbe Interact. 16:851-858.

Kenfielf, D. S., and Strobel, G. A. 1981. $\alpha$-Galactoside binding proteins from plant membranes: Isolation, characterization, and relation to Helminthosporoside binding proteins of Sugarcane. Plant Physiol. 67:1174-1180.

Kim, M. S., Kim, Y. C., and Cho, B. H. 2004. Gene expression analysis in cucumber leaves primed by root colonization with Pseudomonas chlororaphis O6 upon challenge-inoculation with Corynespora cassiicola. Plant Biol. 6:105-108.

Kloepper, J. W., Ryu, C.-M., and Zhang, S. 2004. Induced systemic resistance and promotion of plant growth by Bacillus spp. Phytopathology 94:1259-1266.

Knoester, M., Pieterse, C. M. J., Bol, J. F. and Van Loon, L. C. 1999. Systemic resistance in Arabidopsis induced by rhizobacteria requires ethylene-dependent signaling at the site of application. Mol. Plant-Microbe Interact. 12:720-727.

Moloshok, T., Pearce, G., and Ryan, C. A. 1992. Oligouronide signaling of proteinase inhibitor genes in plants: Structure-activity relationships of di- and trigalacturonic acids and their derivatives. Arch. Biochem. Biophys. 294:731-734.

Mysore, K. S., and Ryu, C.-M. (2004). Nonhost resistance: How much do we know? Trend. Plant Sci. 9:322-331.

Norman, C., Vidal, S., and Palva, E. T. 1999. Oligogalacturonide-mediated induction of a gene involved in jasmonic acid synthesis in response to the cell-wall-degrading enzymes of the plant pathogen Erwinia carotovora. Mol. Plant-Microbe Interact. 12:640-644.

Nürnberger, T., Brunner, F., Kemmerling, B., and Piater, L. 2004. Innate immunity in plants and animals: Striking similarities and obvious differences. Immunol Rev. 198:249-266.

Panikulangara, T. J., Eggers-Schumacher, G., Wunderlich, M., Stransky, H., and Schöffl, F. 2004. Galactinol synthase1. A novel heat shock factor target gene responsible for heat-induced synthesis of raffinose family oligosaccharides in Arabidopsis. Plant Physiol. 136:1-11.

Pennycooke, J. C., Jones, M. L., and Stushnoff, C. 2003. Down-regulating a-galactosidase enhances freezing tolerance in transgenic Petunia. Plant Physiol. 133:901-909.

Peterbauer, T., Lahuta, L. B., Blöchl, A., Mucha, J., Jones, D. A., Hedley, C. L., Gòrecki, R. J., and Richter, A. 2001. Analysis of the raffinose family oligosaccharide pathway in pea seeds with contrasting carbohydrate composition. Plant Physiol. 127:1764-1772.

Pieterse, C. M. J., Van Wees, S. C. M., Hoffland, E., Van Pelt, J. A. and Van Loon, L. C. 1996. Systemic resistance in Arabidopsis induced by biocontrol bacteria is independent of salicylic acid accumulation and pathogenesis-related gene expression. Plant Cell 8:1225-1237.

Pieterse, C. M. J., Van Wees, S. C. M., Van Pelt, J. A., Knoester, M., Laan, R., Gerrits, H., Weisbeek, P. J., and Van Loon, L. C. 1998. A novel signaling pathway controlling induced systemic resistance in Arabidopsis. Plant Cell 10:1571-1580.

Pieterse, C. M. J., Van Wees, S. C. M., Ton, J., Van Pelt, J. A., and Van Loon, L. C. 2002. Signalling in rhizobacteria-induced systemic resistance in Arabidopsis thaliana. Plant Biol. 4:535-544.

Press, C. M., Wilson, M., Tuzun, S., and Kloepper, J. W. 1997. Salicylic acid produced by Serratia marcescens $91-166$ is not the primary determinant of induced systemic resistance in cucumber or tobacco. Mol. Plant-Microbe Interact. 10:761-768.

Radtke, C. W., Cook, S., and Anderson, A. 1994. Factors affecting the growth antagonism of Phanerochaete chrysosporium by bacteria isolated from soils. Appl. Microbiol. Biotechnol. 41:274-280.

Raupach, G. S., and Kloepper, J. W. 1998. Mixtures of plant growth-promoting rhizobacteria enhance biological control of multiple cucumber pathogens. Phytopathology 88:1158-1164.

Ridley, B. L., O’Neill, M. A., and Mohnen, D. 2001. Pectins: Structure, biosynthesis, and oligogalacturonides-related signalling. Phytochemistry 57:929-967.

Ryals, J. A., Neuenschwander, N. H., Willits, M. G., Molina, A., Steiner, H. Y., and Hunt, M. D. 1996. Systemic acquired resistance. Plant Cell 8:1809-1819.

Ryu, C.-M., Hu, C.-H., Reddy, M. S., and Kloepper, J. W. 2003. Different signaling pathways of induced resistance by rhizobacteria in Arabidopsis thaliana against two pathovars of Pseudomonas syringae. New Phytol. 160:413-420.

Ryu, C.-M., Murphy, J. F., Mysore, K. S., and Kloepper, J. W. 2004. Plant growth-promoting rhizobacteria systemically protect Arabidopsis thaliana against Cucumber mosaic virus by a salicylic acid and NPR1independent and jasmonic acid-dependent signaling pathway. Plant $\mathrm{J}$. 39:381-392.

Sambrook, J., Fritsch, E. F., and Maniatis, T. 1989. Molecular Cloning: A Laboratory Manual, 2nd ed. Cold Spring Harbor Laboratory Press, Cold Spring Harbor, NY, U.S.A.

Shigaki, T., and Bhattacharyya, M. K. 2000. Decreased inositol 1,4,5trisphosphate content in pathogen-challenged soybean cells. Mol. PlantMicrobe Interact. 13:563-567.

Simpson, S. D., Ashford, D. A., Harvey, D. J., and Bowles, D. J. 1998. Short chain oligogalacturonides induce ethylene production and expression of the gene encoding aminocyclopropane 1-carboxylic acid oxidase in tomato plants. Glycobiology 8:579-583.

Spencer, M., Ryu, C.-M., Yang, K. Y., Kim, Y. C., Kloepper, J. W., and Anderson, A. 2003. Induced defenses in tobacco by Pseudomonas chlororaphis strain O6 involves at least the ethylene pathway. Physiol. Mol. Plant Pathol. 63:27-34.

Sprenger, N., and Keller, F. 2000. Allocation of raffnose family oligosaccharides to transport and storage pools in Ajuga reptans: The roles of two distinct galactinol synthases. Plant J. 21:249-258.

Sticher, L., Mauch-Mani, B., and Métraux, J. -P. 1997. Systemic acquired resistance. Annu. Rev. Phytopathol. 35:235-270.

Taji, T., Ohsumi, C., Lnchi, S., Seki, M., Kasuga, M., Kobayashi, M., Yamaguchi-Shinozaki, K., and Shinozaki, K. 2002. Important roles of drought- and cold-inducible genes for galactinol synthase in stress tolerance in Arabidopsis thaliana. Plant J. 29:417-426.

Thomma, B., Eggermont, K., Penninckx, I., Mauch-Mani, B., Vogelsang, R., Cammue, B. P. A., and Broekaert, W. F. 1998. Separate jasmonatedependent and salicylate-dependent defense response pathways in Arabidopsis are essential for resistance to distinct microbial pathogens. Proc. Natl. Acad. Sci. U.S.A. 95:15107-15111. 
Ton, J., Van Pelt, J. A., Van Loon, L. C., and Pieterse, C. M. J. 2002. Differential effectiveness of salicylate-dependent and jasmonate/ethylenedependent induced resistance in Arabidopsis. Mol. Plant-Microbe Interact. 15:27-34.

Van Loon, L. C., Bakker, P. A. H. M., and Pieterse, C. M. J. 1998. Systemic resistance induced by rhizosphere bacteria. Annu. Rev. Phytopathol. 36:453-483.

Van Peer, R., Niemann, G. J., and Schippers, B. 1991. Induced resistance and phytoalexin accumulation in biological control of Fusarium wilt of carnation by Pseudomonas sp. strain WCS417r. Phytopathology 91:728-734.

Van Wees, S. C. M., Pieterse, C. M. J., Trijssenaar, A., Van Westende, Y. A. M., Hartog, F., and Van Loon, L. C. 1997. Differential induction of systemic resistance in Arabidopsis by biocontrol bacteria. Mol. PlantMicrobe Interact. 10:716-724.

Verhagen, B. W. M, Glazebrook, J., Zhu, T., Chang, H.-S., Van Loon, L.
C., and Pieterse, C. M. J. 2004. The transcriptome of rhizobacteria-induced systemic resistance in Arabidopsis. Mol. Plant-Microbe Interact. 17:895-908.

Weber, J., Olsen, O., Wegener, C., and Von Wettstein, D. 1996. Digalacturonates from pectin degradation induce tissue responses against potato soft rot. Physiol. Mol. Plant Pathol. 48:389-401.

Wegener, C., Bartling, S., Olsen, O., Weber, J., and Von Wettstein, D. 1996. Pectate lyase in transgenic potatoes confers preactivation of defence against Erwinia carotovora. Physiol. Mol. Plant Pathol. 49:359-376.

Wei, G., Kloepper, J. W., and Tuzun, S. 1991. Induction of systemic resistance of cucumber to Colletotrichum orbiculare by select strains of plant growth-promoting rhizobacteria. Phytopathology 81:1508-1512.

Yan, Z., Reddy, M. S., Ryu, C.-M., McInroy, J. A., Wilson, M., and Kloepper, J. W. 2002. Induced systemic protection against tomato late blight elicited by plant growth-promoting rhizobacteria. Phytopathology 92:1329-1333. 